\title{
SEED-BORNE MYCOFLORA OF LOCAL AND IMPROVED WHEAT (TRITICUM SATIVUM L.) CULTIVARS IN KANO, NIGERIA
}

\author{
*Bashir ${ }^{2}$, M., Mani ${ }^{3}$, M.A and Kutama ${ }^{1}$, A.S \\ ${ }^{1}$ Department of Plant Science, Bayero University, Kano \\ ${ }^{2}$ Department of Applied Biology, Bayero University, Kano \\ ${ }^{3}$ Department of Biology, Kano University of Science and Technology, Wudil \\ Correspondence author:kutamasak@yahoo.com
}

\begin{abstract}
Three varieties each of local and improved wheat (Triticum sativum) cultivars were investigated for seed-borne pathogenic mycoflora using the plate technique and laid on completely randomized design. A total 99 fungal isolate grouped into five fungal species namely; Rhizopus nigricans, Mucor spp, Penillium jenseni, Aspergillus niger, and Fusarium moloniformes were isolated with Rhizopus nigricans, and Fusarium moloniformes (30.30\% and $35.40 \%$, respectively) being the most frequently occurring fungal species and Penillium jenseni $(7.0 \%)$ being the least abundant. Results of the studyhave also indicated that local wheat cultivars were more contaminated than the improved varieties. It is therefore apparent that both improved and local wheat varieties are contaminated by fungal mycoflora.

Keywords; wheat, seed-borne fungi, plate technique
\end{abstract}

\section{INTRODUCTION}

Wheat (Triticum sativum L.) is a world wide cultivated grain known to have originated from the Fertile Crescent region of the near east. World wheat production in 2007 was estimated at 607 million metric tonnes making it the third most highly produced cereal crop after rice and maize (FAO,2010). Wheat is a staple food used to make flour for leavened, flat and streamed breads, biscuits, cookies, cakes, breakfast cereal, pasta noodles, couscous, and for fermentation to make beer, vodka and fuel (Gonzales and Resnicks, 1997). Wheat is planted to a limited extent as forage crop for livestock where the straw is used as fodder for livestock or as a construction material for roofing thatch. However, wheat is continuously attacked by insect pests, parasites and microbial pathogens in the storage, fields, and elsewhere (FAO, 1991). The rate at which wheat is consumed due to its excellent dietary source and the damages done by pests and parasites demands proper attention from the farmers, sellers, and users or consumers. Wheat is subject to mycoflora contamination (Bhutto and Hussain, 1999). These mycoflora are usually transmitted through the seed from the soil (Singh et al., 1997). According to many authors, seed transmission of seed-borne fungi can lead to seed contamination, seed destruction and consequent low yield of the crop (Kutama and Aliyu, 2008; Umar et al., 2009). The aim of this study is to isolate and identify seed-borne pathogenic fungi associated with some local and improved wheat cultivars in Kano, Nigeria.

\section{MATERIAL AND METHODS}

Sample Collection

Three common local wheat (Triticumsativum) cultivars were collected from three major markets in Kano state; Dawanau, Rimi, and Tarauni markets. The wheat seeds locally called yar-gida were aseptically handled by putting them in a sterile polythene bag and labelled properly. Similarly, three improved wheat cultivars were obtained from KNARDA kano agricultural and rural development agency) who are responsible for the breeding, selling as well as distribution of improved seeds in the state (Hassan et al., 2011).

Culturing and Identification of Fungal Isolates In order to obtain a better and a more reliable growth from the various wheat samples, PDA plating technique described by Jha (1995) was adopted. Ten seeds of each cultivar were inoculated on each plate using a sterile forceps. Plates were observed daily for colony growth. Each seed/cultivar was replicated seven times. Slides were prepared (Kutamaet al., 2008) and the microscopies of the isolates were examined as described by Koraet al. (2002) and Bhutta and Hussain(1999) using morphological characteristics. Number of each isolate recovered and their relative abundances were determined.

\section{RESULTS}

The results of the study have demonstrated the presence of four species of fungi, namely; Aspergillus niger, Rhizopus nigricans, Fusarium moliniforme and Mucor spp in the local varieties obtained from Dawanau market while three species of fungi namely; Rhizopus nigricans, Aspergillus niger and Mucor spp at Rimi market and Fusarium moliniforme, Aspergillus niger and Rhizopus nigricans were observed on the local varieties at Rimi and Tarauni markets, respectively. Fusarium specie was found to have the highest number of occurrence among sample from Dawanau and Trauni markets with $35.4 \%$ while it was not detected at Rimi market. 
The number of occurrence of Rhizophusnigricans on the local varieties at Dawanauand Rimi markets was four each while seven isolates were obtained in the samples collected at Tarauni market. Mucorspp was observed on the local varieties sampled from Dawanau and Rimi markets. Furthermore, three fungal species namely; Fusariummoliniforme, Rhizopusnigricans and Penilliumjenseni were observed on the improved varieties, while two species; Aspergillusniger, and Penicilliumjenseni were observed on the improved variety obtained from KNARDA. However, four fungal species Fusariummoliniforme, Rhizopusnigricans, Aspergillusniger and Mucorspp were observed on the improved varieties.

Table 1: Fungal isolates obtained from local wheat cultivars obtained from Dawanau market and their relative abundance (\%)

\begin{tabular}{lcc}
\hline Funga species & Number of isolates & Relative abundance (\%) \\
\hline Aspergillusniger & 4 & 16.0 \\
Rhizopusnigricans & 4 & 16.0 \\
Fusariumoxysporum & 11 & 44.0 \\
Mucor & 6 & 24.0 \\
Total & 25 & 100.0 \\
\hline
\end{tabular}

Table 2: Fungal isolates obtained from improved wheat cultivars obtained from Dawanau market and their relative abundance (\%)

\begin{tabular}{lcc}
\hline Funga species & Number of isolates & Relative abundance (\%) \\
\hline Rhizopusnigricans & 8 & 34.8 \\
Fusariumoxysporum & 9 & 39.1 \\
Fusariumoxysporum & 9 & 39.1 \\
Penicilliumjenseni & 6 & 26.0 \\
Total & 23 & 100.0 \\
\hline
\end{tabular}

Table 3: Fungal isolates obtained from local wheat cultivars obtained from Rimi market and their relative abundance $(\%)$.

\begin{tabular}{lcc}
\hline Funga species & Number of isolates & Relative abundance (\%) \\
\hline Rhizopusnigricans & 9 & 42.8 \\
Aspergillusniger & 5 & 23.8 \\
Fusariumoxysporum & 7 & 33.3 \\
Total & 21 & 99.9 \\
\hline
\end{tabular}

Table 4: Fungal isolates obtained from improved wheat cultivars obtained from KNARDA and Rimi market and their Relative Abundance (\%).

\begin{tabular}{lcc}
\hline Fungal species & Number of isolates & Relative abundance (\%) \\
\hline Aspergillusniger & 3 & 75.0 \\
Penicilliumjenseni & 1 & 25.0 \\
Total & 04 & 100.0 \\
\hline
\end{tabular}

Table 5: Fungal isolates obtained from local wheat cultivars obtained from Tarauni market and their relative abundance $(\%)$.

\begin{tabular}{lcc}
\hline Funga species & Number of isolates & Relative abundance (\%) \\
\hline Rhizopusnigricans & 9 & 42.9 \\
Aspergillusniger & 5 & 23.8 \\
Mucor & 7 & 33.3 \\
Total & 21 & 100.0 \\
\hline
\end{tabular}

Table 6: Fungal isolates obtained from improve wheat cultivars obtained from KNARDA andTarauni market and their relative abundance (\%).

\begin{tabular}{lcc}
\hline Funga species & Number of isolates & Relative abundance (\%) \\
\hline Rhizopusnigricans & 7 & 41.2 \\
Aspergillusniger & 2 & 11.8 \\
Mucor & 2 & 11.8 \\
Fusariumoxysporum & 6 & 35.2 \\
Total & 17 & 100.0 \\
\hline
\end{tabular}

\section{DISCUSSION}

In the present study, seed-borne mycoflora associated with local and improved wheat cultivars were isolated and identified. Among the fungal isolates observed during the study period, Fusarium moliniforme was the major seed-borne pathogen of wheat as revealed by Bhutta and Hussain (1999) that isolated Fusarium moliniforme as the major pathogen from 123, 267 and 246 whet seed lots during 1985-90, 1993-94 and 1996-97, respectively. 
Dawanau market was found to be the site with highest level of contaminated grains probably due to its position as the largest grain market in Nigeria with so many contaminates grains. Similarly, the samples were collected from large basins where the wheat grains are sold, which were exposed to dust and atmospheric pollutants. The local varieties were observed to be more contaminated. This could be attributed to poor method of storage or contaminated farm equipment or in the soil (Mohammed and Kutama, 2007) as the spores of fungi are easily transmitted via seeds due to cracks (Horn, 2003; 2005). From the results of the present study, it is apparent that local wheat varieties contain more seedborne pathogenic fungi than improved cultivars. This was probably because local wheat cultivars are more commonly grown and therefore more vulnerable to attack than improvedvarietiesor that the improved varieties contain genes that confer resistance to fungal attack, and which are not present in the local

\section{REFERENCES}

Bhutta, A.R. and S.S.,Hussain (1999): Seed-borne pathogens of wheat in Pakistan. Rachis 18(2):66-68

FAO (1991): Food and Agricultural Organization Bulletin No. 23. Wheat production

FAO (2010): Food and Agricultural Organization Bulletin No. 5. Wheat production

Hassan, K. Y., S.M. Farouk, Kutama, A.S., and M.L.,Umar (2011) survey of seed- borne mycoloflora of some local sorghum (Sorghumbicolor L.) cultivars and their responses to Apron plus fungicide.African Journal of General Agriculture $7(2): 49-56$

Horn, B.W, (2003): Ecology and population biology of aflatoxigenic fungi in soil. J. Toxol. Toxna Rev. 22:351-359

Horn, B.W, (2005): Colonization of wounded peanut by soil fungi: selectivity for species fronAspergillus section flavi. Mycologia, 23:425-430

Jha, D.K. (1995): Laboratory manual on seed pathology. First edition. Pp2-18

Kora, C., McDonald, M.R. and Boland, G.J. (2005): Occurrence of fungal pathogens of carrot from wooden boxes used for storage. Plant Pathology, 54:663-670

Kutama, A.S. and Aliyu, B.S. (2008): Fungal contamination of local groundnut varieties in northern Nigeria. International Journal Biological Sciences 7(2):52-57

Kutama A.S, Sabo, A.A., Kiyawa, S. A., and Rabiu, M. K. (2008) Isolation and Identification of Post-Harvest Pathogenic Fungi Associated with Fresh Edible fruits sold in Yanlemo Market, Kumbotso LG.A., Kano state, Nigeria. Biological and Environmental Sciences Journal for the Tropics 5(4): 252-255 varieties. This is at par with the report of Singh et al. (1997) and Singh (2005) that some cultivars with resistant gene are less attacked than those without such genes. Local varieties of sorghum and Groundnut were found to be more contaminated than the improved cultivars (Kutamaet al., 2010; Kutama and Aliyu, 2008).

Therefore, to minimize the risk of fungal infection on wheat seed, the following measures are hereby recommended;

1. Wheat should be adequately dried to at least $15 \%$ moisture and kept in air tight container

2. The use of recommended fungicides for seed dressing is also important

3. Storage bins and containers should be cleaned thoroughly each season to remove old grains

4. Improved, disease resistant varieties should be provided by breeders

Kutama, A.S., B., Bashir, and D. James (2010):Incidence of Sorghum Diseases in Dawakin-Kudu Local Govt. Area, Kano state, Nigeria. African journal of General Agriculture 6(4):307-313

Mohammed, A.S. and Kutama, A.S. (2007): Isolation and identification of fungal mycoflora associated with groundnut (Arachishypogea L.) in different storage facilities. Biological and Environmental Sciences Journal for the Tropics 4(1): 131-134

Singh, R. S. (2005) Introduction to principles ofPlant Pathology. Fourth edition. Oxford and IBH Publishing Co.PVT.LTD New Delhi. Pp. 252257

Umar, M. L., A. S., Kutama and S. A., Kiyawa (2009): Detection of Seed-borne Pathogenic Fungi in maize germplasm and their chemical control. Biological and Environmental Sciences Journal for the Tropics 6(3):88-92 